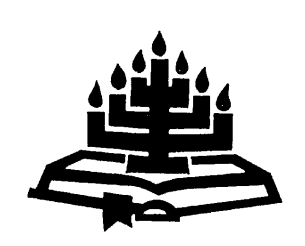

\title{
Tithing: an evaluation of the Biblical background
}

\author{
L. Moretsi \\ School of Biblical Sciences \& Ancient Languages \\ Potchefstroom Campus \\ North-West University \\ POTCHEFSTROOM \\ E-mail: Lekgetho.moretsi@nwu.ac.za
}

\begin{abstract}
Tithing: an evaluation of the Biblical background

Tithe was practised in the Old Testament, but the New Testament emphasises the attitude of the giver. Giving money is about relationships and goodwill. It is important that church members value their churches and commit themselves as constant givers. Tithing can be traced throughout the Old Testament to the New Testament (cf. Heb.). This article will begin with an introduction that offers the practical situation that compelled the institution of the tithe, followed by the Biblical background of tithing and an explanation of the goods or produce that was subject to the tithe. This will be followed by an investigation of the Old Testament perspective on tithing, including a consideration of the first fruits, the offering and the theological implications. Subsequent to this, the New Testament perspectives will receive attention. The NIV translation will be used as it is accepted as a good and reliable translation.
\end{abstract}

\section{Opsomming}

\section{Die gee van fiendes: 'n evaluering van die Bybelse agtergrond}

Die Ou Testament beklemtoon die gee van tiendes, maar die Nuwe Testament beklemtoon eerder die houding van die gewer. Die gee van geld gaan oor verhoudings en toegeneëntheid. Dit is belangrik dat lidmate begaan moet wees oor hulle kerke en dat hulle gereelde bydraers moet word. Spore van die gee van tiendes word telkens in die Ou Testament en ook in die Nuwe Testament gevind (vgl. Heb.). Hierdie artikel begin met 'n inleiding wat die praktiese situasie verduidelik, gevolg deur 'n Bybelse agtergrond en 'n verduideliking van die 
produkte onderworpe aan tiendes. Dit word verder gevolg deur 'n ondersoek aangaande die Ou-Testamentiese siening oor tiendes. Dit sluit in die eerste vrugte of die eerstelinge van die oes, die offers en die teologiese implikasie daarvan. Hierna kry die Nuwe-Testamentiese perspektiewe ook aandag. Die NIVvertaling word hier gebruik, aangesien dit as 'n goeie en 'n betroubare vertaling aanvaar word.

\section{Introduction}

Most black Reformed churches, ${ }^{1}$ especially the ones in the resort of the former synod Midlands, suffer great financial hardship. As a result, churches slip into a total dependency syndrome and accept that this is the way things are and that they cannot change. One cannot ignore the economic and social context of the members belonging to these churches, and this situation contributed to the status of these churches. The reformed teaching initially came with the notion of addressing poverty, improving the lives of these members, and as a result people went to church with the expectation of receiving rather than giving. Stewardship was neglected, so when people came to faith, they had a wrong perception or ideology of what they have come to receive. History teaches that people received (clothes, food, money, etc.), and this became a tradition or a habit that people became accustomed to, from generation to generation. In other words - someone else is responsible for our church (cf. Lekalakala, 2002:13).

The struggle that black Reformed churches face is to transform this mindset. Indeed, in history people received more than what they gave, but that was to address the need of that time. The challenges that the church faced then are not the same as those of today there is a difference in the economy. It lays strain on everyone with the high inflation rate, the rand-dollar exchange rate, brent crude oil and food prices. The number of churches that are able to be of assistance are diminishing, some are combining to be able to carry their ministerial duties, while some are even closing their doors.

Instead of addressing the concept of stewardship or member responsibility before God, the church introduced a flat rate system according to which a ticket is produced as proof of payment. The flat rate system means that all give equally, for all are poor. The church

1 Reformed churches refers to the Gereformeerde Kerke in South Africa. This article specifically refers to the Gereformeerde Kerke with mainly black members. 
introduced a new problem in its attempt to solve the former. Flat rate systems brought a new kind of injustice in the church of Christ, because it teaches that all members give the same amount, for example R5,00 per month, which amounts to R60,00 per year. If you do not contribute, then you owe the church, and this debt is carried forward. If you are able to contribute for the whole year at once, you no longer have any obligation towards the ministry of the church until the following year.

The inconsistency in giving or not giving leads to a total dependency syndrome where it becomes the responsibility of the sister churches ${ }^{2}$ to carry the responsibility of caring for the minister of the black churches and at times all the other ministerial duties. The situation was also such that the church council members were totally uninformed about the stipend ${ }^{3}$ of the minister. The basic issues that arise from this include: What would happen if the helping church is no longer in a position to assist financially, as is already the case in many congregations?; and What if the helping church diminishes in membership numbers and stops existing, as is already happening?

This article argues that tithing, or regular giving as members of the Reformed churches, will indeed improve the financial status of these churches. Members should be encouraged to value the churches they belong to and should be taught that they are responsible for the continuation and fulfilment of the local church's mission and vision, in other words the whole ministry.

It is necessary to state from the outset that the aim of this article is not to promote a prosperity gospel, but to establish Scriptural teaching about the tithe. Teachings persist that Christians under grace in the New Testament dispensation are not obligated to tithe like the Jews in the Old Testament. The church is also confronted with teachings that tithing is not Scriptural (Smith, 2006:15). The purpose of this investigation is to examine Scriptural references in the Old and New Testament, and to discern which principles related to the tithe can be applied to the situation described above.

2 Financially stable or economically strong white Reformed churches in the surrounding neighbourhood who help the poor black churches to maintain their minister. 


\section{The Old Testament background of tithing}

The aim with the following section is not to show all the various forms of giving required, but to focus on tithing.

In the Ancient Near East, tithe included a broad range of property, produce or even currency, but particulars varied from culture to culture. In Israel the following were subject to tithe: grain, new wine (תר), olive oil, fruit, cattle and sheep (Deut. 14:23; Lev. 27:32, etc.), but other items were probably tithed as well (cf. Bromiley, 1988: 861).

Abram tithed spoils of battle (Gen. 14:20) and Jacob vowed to tithe all that God gave him (Gen. 28:22). Carpenter (1988:861) contends that throughout the Ancient Near East, all kinds of objects have been found designated as subject to the tithe: wool, cloth, wood, weapons, gold, silver, donkeys, et cetera. In general, the Israelites had to tithe all the wealth of the land that Yahweh gave to them (cf. Deut. 8:18).

\subsection{Tithing}

The concept of tithe was not new to Israel, since its practice can be observed before the law was handed down (Gen. 14:20; 28:20-22). As early as the time of the patriarchs, the Israelites began to vow tithes (מעשר) (e.g. Gen. 28:22). Sehling (1953:453) mentions that the tithe is mentioned in the Bible as a secular tax (Gen. 47:24; a double tenth for Pharaoh; 1 Sam. 8:15, 17, and Amos 7:1 imply a tax on first fruits). It was originally levied for the king and only later for the deity (a god), which is opposed in Genesis 28:22. Tate (2001:153) maintains that tithing refers to the giving or taking of a tenth of a property, produce or money for some institution or purpose. The Hebrew מעשר, literally "tenth part" or "tithe", is a cognate of the verb עשר , "take the tenth part" (cf. Carpenter, 1988:861).

Genesis 1 indicates that God is the Creator of all the earth's wealth (vs. 11-12; 16-18; 20-21; 24-25; 29-31). As owner of all the land of Canaan, God could give it to whomever He desired (Deut. 2:5; 10 12; 20-23; 31). He gave Canaan to Israel (Deut. 4:1), and Israel was expected to give back to Yahweh a pars pro toto of the produce and wealth of the land. Taylor and Clendenen (2004:414) argues that how Israel regarded and treated the land and its produce was a central feature of their responsibilities under God's covenant. Israel's ownership of the land had to be legitimised by an attitude of faith and gratitude towards God, shown by their use of the land. Israel 
had to keep the Sabbath and to participate in festivals of joy with gifts to God. Ownership also involved the bringing of tithes, through which the landless priest and Levites were provided for (cf. Taylor \& Clendenen, 2004:414). In some cases this involved the first fruits of the land, and in others it involved a tithe of many different items (Deut. 26:1-15; Carpenter, 1988:862).

Averbeck (1997a:1036) argues that מעשר occurs in the Old Testament as often as 32 times: seventeen times in the pentateuch, five times in the prophets, and ten times in the writings. There are 29 references to the tithe where the sons of Israel had to give to the Levites, and the Levitical tithe to the priests. It refers once to Abram's tithe to Melchizedek (Gen. 14:20). Ezekiel 45:11, 14 refers twice to the regulation of the size of a bath volume measurement as a "tenth of homer", and "the prescribed portion of oil ... a tenth of a bath from each cor" for the offering to make atonement for Israel (cf. Averbeck, 1997a:1035). Ezekiel 45 is the only passage where מעשר is used simply as a measure, not in reference to tithes. The major texts describing the Lord's commands regarding tithing are Leviticus 27:30-33; Numbers 18:21-32; Deuteronomy 12:1-18 (esp. verses 6 ff.; 11 ff.; 17-19); 14:22-29; 18:1-4; 26:12-15. These verses outline the three tithes in the ancient Israel: the general tithe (Lev. 27 and Num. 18); the tithe of the sacred meal with the Levite (Deut. 14:22$27)$; and the tithe paid every three years to the poor (Deut. 14:28-29) (cf. Rooker, 2000:328).

De Vaux (1961:141) states that the final stage of contribution of tithes dawned as theocracy was instated after the return from exile. The people solemnly undertook to pay to the temple a third of a shekel annually, the first fruits of the earth and the flocks, a tithe on the soil and certain offerings of wood (Neh. 10:33-40). Law (2007: 138) argues that the temple was more than a centre of worship in ancient Israel. By nature of its economic importance, the temple in ancient Israel served government as well as God. Trustworthy men were charged with collecting, storing and distributing these revenues (Neh. 12:44-47; 13:10-13). Kings paid the normal expenses of the public worship and the cost of repairs to the building.

\subsection{The first fruits}

According to the writer of Proverbs (3:9), the first fruits should be given to God to honour God with the best the believer has. This verse does not concern itself so much with ceremonial religion, but it is exhorting the reader to demonstrate gratitude towards and 
confidence in God. In fact, the first fruits of all produce should be given to God's work (Lev. 27:30-32; Num. 28:26 ff.). Grissen (1992:33) reminds that the Bible tells people to give their first fruits back to God (cf. Num. 15:17-21; Rom. 11:16). Honouring God with the first fruits becomes one of the means of reminding every generation of the goodness and faithfulness of God (cf. Cole, 2000:248). A part of the dough had to be offered to God as a symbol that the entire lump belonged to Him. The same idea is involved in the feast of the first fruits. Leviticus 23:9-14, where the priest offers a sheaf to the Lord as a token, symbolises that the entire harvest belongs to Him. The following verses also refer to the firstlings or first fruits of various things: Exodus 13:2; 23:2; 23:10 ff.; 23:6; 15:1821. It is clear here that the first fruit of all things belongs to the Lord. Exodus, Leviticus and Deuteronomy speak of the first fruits of the crops, the harvest of grain, the animals, wool, wine and oil. In Psalm 78:51 we read: "He struck down all the firstborn of Egypt, the first fruits of manhood in the tents of Ham." Here firstborn is referred to as first fruits.

\subsection{The offerings}

Taylor and Clendenen (2004:416) argues that the term offerings is a translation of the word teruma, which traditionally means "heave offerings" (e.g. Exod. 29:27-28; Lev. 7:14.32; Num. 15:19-21). The term occurs 76 times in the Hebrew Bible, mostly in Numbers, Exodus and Ezekiel, and it is associated with the causative of the verb rûm, "be high", suggesting the raising of an offering to God (cf. Taylor \& Clendenen, 2004:416). Malachi 3:8 reads: "Will a man rob God? Yet you robbed me. But you ask, 'How do we rob you?' In tithe and offerings". Schuller (1996:870) argues

This whole unit is concerned specifically with failure in the payment of tithes (i.e. one-tenth of agricultural produce, from both livestock and produce); the 'offering' in verse 8 is a technical term for the one-tenth of tithe given to the Levites, which was in turn given to God (Num. 18:25-32). Both the deuteronomic (Deut. 14:22-29; 26:12-15) and the priestly (Lev. 27:30-33; Num. 18:21-32) codes developed extensive legislation governing the exact tithes due, where they had to be taken, and the rights and privileges of both Levites and Aaronite priests to receive set portions for their support.

The giving of one tenth was a compulsory contribution in the Mosaic law. It was acknowledged that a tithe of everything from the land, whether grain from the soil or fruit from the trees, belongs to the 
Lord (Lev. 27:30). Also "the entire tithe of the herd and flock - every tenth animal that passes under the shepherd's rod - will be holy to the Lord" (Lev. 27:32). Tithe was neglected, and therefore Malachi emphasises it. According to Sprague (2002:17), tithing is the 10\% that you give to your local church, and an offering is any gift above $10 \%$ of your income that you give to any ministry to which the Lord directs you. Tithing was stipulated in Jewish law, and Christians are freed from that law. Achtemeier (1986:191) argues that there is no comparable duty to tithe laid upon Christians in the New Testament, though the book of the New Covenant is full of urgings to charity and giving as appropriate responses of gratitude and services to God. Offering is a respond in faith towards the love of God.

Sin offering and other offerings have been fulfilled in Christ (cf. John 1:20; Matt. 26:28; Rom. 3:25; Heb. 9 esp. v. 26). Our lives have to be a thanksgiving sacrifice (cf. Rom. 12:1). How much must one then give? Makwakwa (1997:12) argues that individuals determine how much they want to give to God.

The church offerings or gifts in the New Testament fulfils the Old Testament idea of sacrifice or offering. It is the fulfilment of thanksgiving (cf. Venter, 1956:131). The New Testament emphasises giving rather than tithing. 4

It is clear in the Old Testament that tithing was a way of life. Johnson (1984:36) holds:

Evidently the tithe was assumed by Jesus as legitimate as any other law. He did not mention the tithe as requirement, but his teachings did not undercut any existing religious law.

It is significant to know that Christ was not trying to replace the law with something new; He was asking people to look beyond it to see what the words meant, not what they said (cf. Matt. 5:17-19). The New Testament speaks of giving as people are able, not about a law that requires everyone to give a tenth or a tithe to support a group of priests. Johnson (1984:22) argues that the tithe, when based on the spiritual interpretation of the Old Testament, is not legalism. Tithe is demanded by the law. The tithe of the Old Testament is a testimony to the interconnectedness of people and God. Tithing is still valid in

$4 \quad$ Giving according to the New Testament is not an external obligation but rather an expression of love from the regenerated and redeemed heart whilst tithing is an external obligation as dues from a member. 
the New Testament, although the attitude 5 of the giver is emphasised. Voluntary giving in the Old Testament reveals that from the beginning the attitude of the giver was of paramount importance to God (cf. Van Rensburg, 2002:149).

\subsection{Theological implications}

By giving the tithe, the Israelites were solemnly declaring that they were giving a portion back to the One who had made them prosperous (cf. Deut. 26:10-15). By giving the tithe they also recognised the validity of the priests' and Levites' role as God's representatives and acknowledged their right to receive support for the spiritual service they performed on the people's behalf. Both the priests and the Levites did not own any property and they were responsible for all the religious duties in the temple. This provided them an opportunity to remember Yahweh's blessings as He had remembered them, and to imitate God's care for slaves, the poor, orphans and widows (cf. Carpenter, 1988:863).

The tithe demanded that the Israelites serve their God at a significant cost to themselves. In this amazing system of tithing, Israel's economics became a channel for expressing love to God and love to their neighbours - the heart of the Torah (Deut. 6:4-9; Lev. 19:18) (Carpenter, 1988:863).

Deuteronomy 14:16 makes paramount the joy and fellowship of presenting the tithe in a family context. The reforms under Hezekiah (2 Chron. 31:4) and Nehemiah (Neh. 10:37; 13:10-14) emphasised the seriousness of neglecting the support of the Levites, God's appointed ministers (cf. Carpenter, 1988:863). Finally, tithing helped to set Israel apart as Yahweh's people and His alone, a people holy to Him (Deut. 14:22-29). The blessing reinforced Israel's reverence to Yahweh and their sense of belonging to Him (Deut. 14:29).

\subsection{Summary of the Old Testament perspective}

Tithing one's property or produce to support religious institutions or the priesthood is something which has been practiced for a long time. It is an ancient practice. In the Old Testament several kinds of offerings and sacrifices were made and tithing was prescribed. The

5 This is a reference to the heart, i.e. whether the giver does this willingly with a happy heart in response to God's grace or whether he/she does this because the law forces him/her to give. 
commandments in the Old Testament emphasise the quality (onetenth) of the gift. In this lies the belief that God is entitled to share directly in the grain, wine, and oil that humans are permitted to produce. Flocks and herds had to be tithed as well. The Old Testament emphasises tithe, that is the giving of one tenth, as a principle.

\section{The New Testament background of tithing}

Richards (1985:308) argues that although the principle of tithe predates the law (Gen. 14:20; 28:22), no instruction in Acts or in the epistles suggests that tithing should be practised by Christians. He argues that a new set of principles (sharing, cheerful giving, voluntary giving) has been set that reflect new theological and social realities.

Several New Testament passages refer to tithing. 2 Corinthians 9:713 alludes to the practice, although it does not specifically mention it. In Matthew 23:23, Luke 11:42 and 18:12 giving of tithes is cast in a negative light because of the way it was often practised with no regard for justice, the love for God, mercy and faith. The fourth woe in Matthew 23:23 indicates the preoccupation of the Pharisees with minutiae and the resultant neglect of things that really mattered (Hagner, 1995:670; Blomberg, 1992:345; Stein, 1992:340). The Pharisees even tithed herbs such as mint, dill and cummin (cf. Lev. 27:30; Deut. 14:22-23). The central truth of Luke 18:9-14 is that humility is more pleasing to God than a haughty and perfunctory performance of religious duties (cf. Smith, 1984:334). It is also mentioned or referred to in Hebrews 7:1-10. In preparation for the explication of the high priest who would arise after "the likeness of Melchizedek", the writer concerns himself in Hebrews 7:1-10 with the ancient priestly model that prefigured the messianic priest (cf. Lane, 1991:171). Abraham's allotment of a tenth of the plunder to Melchizedek and Melchizedek's blessing of Abraham, shows that Melchizedek was superior to Abraham. Melchizedek derives his significance from the Son. Averbeck (1997a:1054) points out that tithing is conspicuous in its absence in the New Testament instruction regarding giving in the New Testament church (Rom. 15:25-28; 1 Cor. 9:6-18; 16:1-3; 2 Cor. 8-9; Eph. 4:28; cf. Hawthorne, 1978:854).

\subsection{New Testament concept of tithing}

The New Testament faith community has no uniform identity, as is the case with the Old Testament community. Feinberg (1977:758) 
states that in the time of the New Testament, changes had taken place (Luke 11:42; 18:12). Paul's exhortation to give with a cheerful heart (2 Cor. 9:7) reflects Deuteronomy's instruction about tithing, which emphasises the importance of rejoicing (e.g. Deut. 12:7, 11 ff., $17 \mathrm{ff} ., 14: 26)$. Koinonia expresses the idea of sharing and fellowship. It affirms the reality of a bond created with faith in Christ - a bonding to God and to those who belong to God. One should therefore not see this as doing away with the Old Testament concept, but rather a matter of emphasising the attitude with which one gives.

Richards (1985:309) reminds that in the New Testament giving is portrayed as a way to provide support for those who give their full time to ministry (Gal. 6:6; 1 Tim. 5:17-18). It is also a way to meet the needs of local people who have no family to help them when they cannot care for themselves (1 Tim. 5:16). However, the major New Testament emphasis is on a societal concern: Christians should share with others who, because of natural disasters, cannot survive without help. It presents tithe as systematic giving. Instead of suggesting tithe as a measure, Paul (2 Cor. 8-9) provides several principles as guidance:

- Giving is an expression of love. It should be prompted by inner concern for others that cannot be commanded, but must be a free and spontaneous act (2 Cor. 8:8).

- Giving should be a balanced response, measuring what a person has against the current needs of others (2 Cor. 8:12-15).

- Giving is an act of faith. It shows trust in God, who is "able to make all grace about to you" (2 Cor. 9:8). As we give generously, God will supply in our needs and enable us to "be generous on every occasion" (2 Cor. 9:11).

- Giving has many benefits. It meets the needs of brothers and sisters and stimulates praise to the Lord. It also stimulates prayer both for the giver and the receiver (2 Cor. 9:11-14).

- Giving follows the example of Jesus. "Though He was rich, yet for your sake He became poor, so that you through his poverty might become rich" (2 Cor. 8:9). Giving is an appropriate way to express our appreciation to God for his own indescribable gift (2 Cor. 9:15).

Carpenter (1988:863) argues that the author of Hebrews (Heb. 7) uses the account of Abram paying a tithe to the priest king 
Melchizedek (Gen. 14:18-20) to show the superiority of Christ's priesthood, which is "after the order of Melchizedek" (Heb. 7:7, 17). One may therefore conclude that this process calls for the most responsible behaviour from people. The New Testament emphasises giving rather than tithing.

Wilson (1992:579) states that tithes receive very little attention in the New Testament. Although this is the case, the law of tithing was never abolished in the New Testament. In fact, Jesus validated it. Coetzee (1992:26) points out: "We read nowhere that Jesus and his disciples cancelled the bringing of the tithe". In Mark 12:41 we read: "Jesus sat down opposite the place where the offerings were put and watched the crowd putting their money into the temple treasury." With regard to giving, what Christ said about the widow's gift is more reflective of God's spirit than of those who had more to give. He said that her small gift was greater than their larger tithes. In addition, He said that because she gave her money without reservation, but with a willing heart, and did not want to be noticed, God would more likely look upon her favourably. In Matthew 23:23 and Luke 11:42 Christ criticised the Pharisees for giving their tithes without love. He then says: "You should have practised the latter, without neglecting the former (the giving of tithes)" (cf. Stein, 1992:340). The tithes were for the temple services.

Hebrews 7 reflects that in Abraham the whole people of God gave tithes to Melchizedek, because he was in fact representing Christ (cf. Lane, 1991:172). So the principle that Christ should be honoured as the Priest and King by giving tithes should be maintained. Venter (1956:130) holds: "From this it can be deduced that tithing is as old as the shadow and it therefore cannot fall away". These are the places where tithing is clearly mentioned, and it is connected to the temple services. In the New Testament, emphasis is on the gratitude of the giver who gives from the heart and gives freely and willingly. It is an individual responsibility to give in proportion to God's blessings (cf. Deut. 16:17; 1 Cor. 16:2). It becomes more evident that the New Testament emphasises the attitude with which one gives, instead of only the act of giving. The attitude must accompany the act. As stewards, God awaits a tithe. Fourie (1996:20) points out that "not being able to give back from that which God gives me, for my livelihood or sustenance and action or attitude in this world is a gross/rude unthankfulness". The attitude of being self centred and selfish, as if what one has, is because of one's own doing, is wrong. God is the source of all things that man possesses, and as a steward, man has to give a portion back. It is important to note that 
the giving does not determine man's salvation, but it is an act of gratitude.

In 2 Corinthians 8:7-9 Paul refers to the act of giving as an act of grace (cf. Garland, 1999:379). He further states that one should excel in this act of giving and not take it for granted. Moreover, this is a matter of sincerity and earnestness. The basis for this grace of giving is the sacrificial work of Jesus Christ. He became poor in order for his followers to become rich. The recipients of this grace are not required to have done anything to receive this gift. It is this grace that makes the givers generous, because God' $s$ grace is working on them, in them and through them. This also happens in Psalm 116:12 where the psalmist realises that he has been saved from death and asks: How can I repay the Lord for all his goodness to me? In verse 17 he speaks of giving and then says: I will sacrifice a thank offering to you.

Once more the matter of attitude is emphasised. In this text Paul adds the basis for giving to the attitude. This basis is the work of Christ, as well as his grace. It is thus clear that the tithe in the New Testament context is connected to the idea of offering in the Old Testament, that is, the thanksgiving sacrifice or offering (cf. Rom. 12:1). Tithing should be done with the attitude of the spirit of gratitude. God wants selfless giving or sacrifices from his people (cf. 2 Cor. 8:2-5). Giving to God needs total involvement and commitment. Tithe, or to give, must be based on the Biblical principle. The New Testament emphasises the attitude of the giver's heart. Christ warns his people not to let their pride take over by making a display of their giving (Matt. 6:3).

\subsection{Summary of the New Testament perspective}

In the New Testament church, the tithing (giving) was not based on a prescriptive formula, such as tithing in the Old Testament. The New Testament tithing is never mentioned as a principle for the New Testament church and this poses many problems. Rather tithing in the New Testament is based on the individual believer's response to the grace of God in Christ which he/she had experienced in salvation. In the New Testament there are only a few references to tithing (Matt. 23:23; cf. Luke 11:42; 18:12; Heb. 7:6; 8-9). Practicing of fellowship of the saints meant giving, particularly when done to those in need.

The New Testament emphasises giving, that is, giving according to willingness or means, but it does not prescribe a specific amount 
that one should give. Tithe is a principle for both the Old and New Testaments.

\section{Conclusion}

The Old Testament contains laws pertaining to tithing, sacrifices and offerings, as well as everyday living. The Old Testament pattern of giving was an integral part of the social system that was established in the Mosaic law. The people practised the giving of one-tenth. One significant factor with regard to giving is that it was done in proportion to what one had. Christ's total self-giving alone constitutes the basis for Christian giving: "Freely you have received, freely give" (Matt. 10:8). It is clear that the Old Testament contains laws pertaining to tithe, sacrifices and offering. Throughout the Old Testament, tithe was practiced. The traces of tithe are found in the pre-Mosaic era, the pentateuch, the prophets and the writings.

Tithing in the New Testament is not as formal as in the Old Testament. The New Testament stresses giving in response to God's love. It emphasises the attitude of the heart and not on how much should be contributed. The Old Testament maintains giving of one tenth (tithe, which is according to what one prospered), while the New Testament does not give any instruction on a tithe except to maintain the principle of giving as one has prospered and according to one's means. As a matter of fact, the principle is maintained throughout the Old and New Testament. Since the New Testament does not give any specific instruction on the amount, tithe can be considered as a guiding principle. The New Testament does not prescribe a tithe, but giving according to ability is a principle. This is the opposite of a flat rate. Tithing is a principle emphasised in the Old Testament. The principle of giving is continued in the New Testament, and man as a steward is obligated to fulfil. It is, however, a discontinuity in a manner in which man in the New Testament fulfil this obligation.

In conclusion, with the above in mind, the modern church, especially churches in the former synod Midlands, need to pay serious attention to its practice in this regard. It is my conviction that if the principle of constant giving or tithing can be implemented, the financial situation of these churches will change for the better. It is now time that these churches pay serious attention to stewardship, discipleship and encourage regular and constant giving. This can be done through education, especially aimed at the youth with a view to future progress. The church must have a well-planned regular 
method of giving. The law demands a tithe, but as steward, man with all that he has belongs to God.

\section{List of references}

ACHTEMEIER, E. 1986. Interpretation: a Bible commentary for teaching and preaching: Nahum-Malachi. Atlanta: Knox.

AVERBECK, R.E. 1997b. Terumar. (In Vangemeren, W.A. New International Dictionary of the Old Testament Theology and Exegesis. Vol. 4. Grand Rapids: Zondervan. p. 335-338.)

BIBLE. 1988. Life application study Bible. King James version. Wheaton: Tyndale.

BIBLE. 1989. Life application study Bible. New international version. Wheaton: Tyndale.

BLOMBERG, C.L. 1992. The new American commentary: an exegetical and theological exposition of Holy Scripture. NIV text. Vol. 22: Matthew. Nashville: Broadman.

CARPENTER, E.E. 1988. Tithe. (In Bromiley, G.W. The International Standard Bible Encyclopaedia. Vol. 4: Q-Z. Grand Rapids: Eerdmans. p. 861-864.)

COETZEE, P.J. 1992. Gee u ook u oorskiet aan die Here? Die Kerkblad: 26-27, 11 Maart.

COLE, R.D. 2000. The new American commentary: an exegetical and theological exposition of Holy Scripture. Vol. 3B: Numbers. Nashville: Broadman \& Holman.

DE VAUX, R. 1961. Ancient Israel: its life and institution. Norwich: Fletcher.

FEINBERG C.L. 1977. Tithe. (In Tenney, M.C. The Zondervan pictorial encyclopaedia of the Bible. Vol. 5: Q-Z. Grand Rapids: Zondervan. p. 756758).

FOURIE, B.C.G. 1996. My kerklike bydrae. Die Kerkblad: 20-21, 25, 12 Jun.

GARLAND, D.E. 1999. The new American commentary: a exegetical and theological exposition of Holy Scripture. Vol. 29: 2 Corinthians. Nashville: Broadman \& Holman.

GRISSEN, L.V. 1992. First-fruits: managing the master's money. Orlando Park: Barnabas Foundation.

HAGNER, D.A. 1995. Word Biblical commentary: Matthew 14-28. Texas: Word Books.

HAWTHORNE, G.F. 1978. Tithe. (In Brown, C. The New International Dictionary of the New Testament Theology. Grand Rapids: Zondervan. p. 851-855.)

JOHNSON, D.W. 1984. The tithe: challenge or legalism? Nashville: Abingdon. (Creative leadership series.)

LANE, W.L. 1991. Word Biblical commentary: Hebrews 1-8. Texas: Word Books.

LAW, T.M. 2007. The forgotten function of the temple in Ancient Israel. The expository times, 119(3):138-139.

LEKALAKALA. M.J. 2002. Synod Midlands: reformation or deformation? A battle for survival. Makolokwe: Lekalakala.

MAKWAKWA, B.W. 1997. Giving to God is the best investment. Pretoria: State Library. 
RICHARDS, L.O. 1985. Expository dictionary of Bible words. Grand Rapids: Zondervan.

ROOKER, M.F. 2000. The new American commentary: an exegetical and theological exposition of Holy Scripture. Vol. 3A: Leviticus. Nashville: Broadman \& Holman.

SCHULLER, E.M. 1996. The Book of Malachi: introduction, commentary and reflection. (In Keck L.E. The new interpreter's Bible: a commentary on twelve volumes. Vol. 7. Nashville: Abingdon. p. 869-870.)

SEHLING E. 1953. Tithes. (In Jackson, S.M. The new Schaff Herzog encyclopaedia of religious knowledge. Vol. 11. Grand Rapids: Baker. p. 435-456.)

SMITH L.R. 2006 Tithing is unscriptural under the new covenant. http://www.bible-truths.Com/tithing.html Date of access: 24 Oct. 2008.

SMITH, R.L. 1984. Word Biblical commentary. Vol. 32: Micah-Malachi. Texas: Word Books.

SPRAGUE, R.I.N. 2002. The money is in the mantle: the economic alliance of prophets, priests and kings. Durban: Kairos.

STEIN, R.H. 1992. The new American commentary: an exegetical and theological exposition of Holy Scripture NIV Text. Vol. 24: Luke. Nashville: Broadman.

TATE, M.E. 2001. Tithing: legalism or benchmark? Review and expositor, 70(2):153-161.

TAYLOR, R.A. \& CLENDENEN, E.R. 2004. The new American commentary: an exegetical and theological exposition of Holy Scripture: Haggai, Malachi. Nashville: Broadman \& Holman.

VAN RENSBURG, R.D. 2002. Tithe and offering in the South African context: The Bible and reality. Zululand: University of Zululand.

VENTER, A.A. 1956. Die tiendes. (In GKSA. Almanak van Gereformeerde Kerk in S.A. Potchefstroom: Administratiewe Buro. p. 121-134.)

WILSON J.C. 1992. Tithe. (In Freedman, D.N. The Anchor Bible Dictionary. Vol. 4: K-N. New York: Doubleday Dell. p. 578-580.)

\section{Key concepts:}

first fruits

giving, voluntary

offering

sacrifice

tithe

\section{Kernbegrippe:}

eerste vrugte

gee, vrywillig

offer

opoffering

tiende 
